\title{
Assessment of Soil Loss from Agricultural Lands of South Andaman District in Tropical Islands
}

\author{
B.K. Nanda ${ }^{1 *}$, N. Sahoo ${ }^{2}$ and B. Panigrahi ${ }^{2}$ \\ ${ }^{1} I C A R-K V K$, Port Blair, India \\ ${ }^{2}$ Department of Soil and Water Conservation Engineering, CAET, OUAT, \\ Bhubaneswar, India \\ *Corresponding author
}

\section{Keywords \\ Crop land, \\ Erosivity, Land degradation, Soil loss, Tropical islands \\ Article Info \\ Accepted: 18 February 2019 Available Online: 10 March 2019}

\begin{abstract}
A B S T R A C T
Soil loss was estimated from agricultural lands of South Andaman district in tropical Bay Islands applying Universal Soil Loss Equation (USLE). Mean annual rate of soil loss to the tune of $184.1 \times 10^{3}$ tons was estimated from the crop fields of the district covering 1747.0 ha area at the rate of $105.38 \mathrm{t} \mathrm{ha}^{-1} \mathrm{yr}^{-1}$. In South Andaman district, kharif crops (rice, maize, arhar, ground nut, ginger, sweet potato, tapioca and turmeric) are grown in medium to low lands whereas rabi crops (pulses and vegetables) are grown in uplands. The cropping intensity is $104.0 \%$. Maximum (136.8 thousand tons) and minimum (0.06 thousand tons) soil loss was obtained from the cultivation of vegetables (1317.0 ha) and arhar $(0.5 \mathrm{ha})$, respectively. The highest $\left(124.8 \mathrm{t} \mathrm{ha}^{-1} \mathrm{yr}^{-1}\right)$ and the lowest $\left(70.6 \mathrm{t} \mathrm{ha}^{-1} \mathrm{yr}^{-1}\right)$ rate of soil loss were obtained from the cropping pattern of rice-fallow-fallow and gingerfallow, respectively. Among the double cropped land, the sequence of sweet potatovegetable-fallow contributes the lowest rate of soil loss $\left(68.76 \mathrm{t} \mathrm{ha}^{-1} \mathrm{yr}^{-1}\right)$, whereas the cropping sequence of rice-fallow-vegetable yielded the highest rate of soil loss (106.25 t $\left.\mathrm{ha}^{-1} \mathrm{yr}^{-1}\right)$. The average rate of soil loss from double cropped land is $86.02 \mathrm{tha}^{-1} \mathrm{yr}^{-1}$. The study reveals that converting more mono crop area into double cropped land will reduce the average soil loss annually by $18.4 \%$.
\end{abstract}

\section{Introduction}

In India, out of $328.0 \mathrm{M}$ ha, 147.0 million ha $(44.8 \%)$ area is suffering from various forms of land degradation (Bhattacharyya et al., 2015). Panigrahi et al., (2009) stated that any form of agriculture involves alteration of ecological system and causes large scale land degradation. Agriculture can result in soil erosion when improper management is applied on arable land (Oldeman, 1997). Pimentel et al., (1995) reported that nearly one-third of the world's arable land has become unsuitable for cultivation due to water erosion only. Major portion $(98.0 \%)$ of total soil loss from a watershed is from the cultivated croplands. As a result of which, the total annual loss of productivity of major crops in India is 7.2 million tonnes (Brandon et al., 1995; Suresh et al., 2002; Naik et al., 2015). The tune of soil 
loss from the cropped lands in islands is generally higher in comparison to the croplands in plain area due to undulating topography characterized with hills, hillocks and flat bottomed valleys (Pandey et al., 2007).

The Andaman and Nicobar group of islands in India were once upon a time thickly covered with tropical rain forests and were settled in mid-twentieth century. The settlers were provided with 2.0 ha forest land on the hillocks and 2.0 ha lands in the valleys. Those settlers removed the forests, constructed houses and planted trees round the houses that met their maximum basic needs because markets as well as roads were not available at that time. This led to the development of home garden in the islands. At present coconut and areca nut plantations as well as home gardens are second major land uses after forests (Pandey et al.,2007). Some portion of the cleared forest lands are in use for vegetable cultivation by farmers. Generally, farmers perform deep soil working in the vegetable fields and remove weed for the vegetable cultivation. They mainly follow vegetablevegetable and ground nut-vegetable rotations in the vegetable fields. Before Tsunami that devastated these islands in 2004, 12,000 ha land in the valley was under bunded paddy cultivation (Pandey et al., 2007). Tsunami has already engrossed about 4000 ha low-lying rice fields in the islands and several thousand hectare lands (rice fields) are still being inundated once in a day by high tides making them unfit for rice cultivation. These islands experience torrential and high rainfall during wet season from South-West monsoon (Pandey et al., 2007). Agricultural activities, particularly vegetable cultivation exposes surface soils to the rainfall which carry away a huge amount of top fine soil particles to the Andaman Sea in Bay of Bengal through lowlying streams and makes soil deficient in nutrients (Pandey and Singh, 2009). Loss of soils is found to increase many folds in hilly area due to accelerated rate of runoff (Narain et al., 1998). The land mass of the islands is precious not only from the soil fertility point of view, but also for the existence of the islands as well. Land use wise information on soil erosion estimated using run off plot, so far, is not available for these islands because it is expensive and time consuming (Velmurugan et al., 2008). Velmurugan et al., (2008) carried out soil erosion study in Dhanikhari watershed of the district using revised Morgan and Morgan Finney model with an aid of remote sensing and GIS. But no ground truthing was carried out for a long term (even not for one annual cycle) to validate the results of the model due to extreme backwardness and inaccessible area.

The rising population, limited cropping land and more food requirement has resulted in the extension of cultivated area on steep slopes in these regions which are vulnerable to erosion. Undulating terrain, high intensity monsoon rainfall and run off and severe soil erosion are the major problems of these islands. Keeping these land degradation problems in view, an attempt has been made under the present study to quantify the soil loss from the agricultural lands of South Andaman district applying the Universal Soil Loss Equation (Wischmeier and Smith, 1978). Soil loss from agricultural lands may be quite helpful in planning suitable conservation measures.

\section{Materials and Methods}

South Andaman district lies between latitudes of $6^{\circ} 45^{\prime} \mathrm{N}$ to $13^{\circ} 4^{\prime} \mathrm{N}$ and longitudes of $92^{\circ}$ $15^{\prime} \mathrm{E}$ to $94^{\circ} \mathrm{E}$ at an elevation of $13.0 \mathrm{~m}$ from mean sea level. The total available land for utilization in the district is 280.4 thousand ha which is $90.3 \%$ of the total geographical area of these groups of islands. Forest area, net sown area, current fallow land, fallow land other than current fallow land, other 
uncultivated land excluding fallow land and land not available for cultivation constitutes $95.3 \%, 2.5 \%, 0.1 \%, 0.5 \%, 0.7 \%$ and $0.9 \%$ of the total reporting area for land utilization respectively (District Statistical Hand Book, 2011). Soils of South Andaman districts are low in $\mathrm{N}, \mathrm{P}$ and organic matter content and are predominantly red, mixed red and yellow having sandy loam to sandy clay loam texture. The annual normal rainfall in the district is $3054.2 \mathrm{~mm}$ distributed over 131.1 rainy days. The daily rainfall data since last 30 years (1987-2017) indicates that these groups of islands receive $72.5 \%$ of the total normal rainfall due to South-West monsoon recorded in 91 rainy days (ICAR-CIARI, 2017; ICARKVK, 2018). May to November is the usual wet period, where $90.4 \%$ rainfall is recorded in about 117.3 rainy days. Most of the monsoon rain water is let off as high speed free surface flows which has a scour potential and inflicts tremendous loss of valuable top soil converting the feasible fields into unfeasible fallow fields. More fallow fields and land degradation cause continuous decrease in net sown area in the district.

These Islands fall under agro-climatic zone $\mathrm{XV}$ and have a true maritime climate of warm and humid with mean maximum and minimum temperatures of $31^{\circ} \mathrm{C}$ and $21^{\circ} \mathrm{C}$, respectively. Relative humidity varies from $67 \%$ to $95 \%$ in monsoon and $56 \%$ to $84 \%$ in off season. Bright sunshine hours vary from 0 to 11.3 hours in monsoon period and from 0 to 11.1 hours in post monsoon season. The mean wind velocity varies from $2.7 \mathrm{~km} / \mathrm{hr}$ to 28.2 $\mathrm{km} / \mathrm{hr}$ in monsoon period and from $2 \mathrm{~km} / \mathrm{hr}$ to $14.6 \mathrm{~km} / \mathrm{hr}$ in post monsoon period. Detailed information on land uses, soil type, major crops/cropping pattern and rainfall in respect of South Andaman district were collected from secondary sources and published literature (District Statistical Hand Book, 2011) and (ICAR-CIARI, 2017). Other relevant information on physical characteristics of the crops were collected from Annual Reports of ICAR-KVK, Port Blair (ICAR- KVK, 2018).

For predicting soil erosion, Universal Soil Loss Equation, popularly known as USLE model (Wischmeier and Smith, 1978) is most widely used throughout the world for estimating annual soil loss from agricultural lands (Ahmad and Verma, 2013; Naik et al., 2014) and is given in Eq. (1) as:

\section{$\mathrm{A}=\mathrm{R} \mathrm{KL} \mathrm{S} \mathrm{C} \mathrm{P} \mathrm{(1)}$}

Where, $\mathrm{A}$ is the average soil loss (tons $\mathrm{ha}^{-1} \mathrm{yr}^{-}$ $\left.{ }^{1}\right), \mathrm{R}$ is the rainfall erosivity factor (metric ton.m/ha.hr), $\mathrm{K}$ is the soil erodibility factor, $\mathrm{L}$ is the slope length factor, $\mathrm{S}$ is the slope gradient factor and $\mathrm{P}$ is supporting conservation practice factor.

Rainfall erosivity factor (R) was estimated using rainfall data from 1978 to 2016. Erosivity factor values for each erosive storm were computed for 30 minutes rainfall intensity using the following empirical equation (Raghunath and Erasmus, 1971) as stated in Eq. (2).

\section{$\mathrm{R}=\left(\mathrm{KE} \times \mathrm{I}_{30}\right) / 100(2)$}

Where,

$\mathrm{R}=$ Erosion index in metric ton. $\mathrm{m} / \mathrm{ha} \cdot \mathrm{hr}$

$\mathrm{I}_{30}=$ Maximum 30 minutes rainfall intensity, $\mathrm{cm} / \mathrm{hr}$ which is calculated from each storm event using recording raingauge chart and $\mathrm{KE}=$ Kinetic energy of the strom in metric ton.m/ha.cm which was computed by Eq. (3) as proposed by Wischmeir (1959) as:

$\mathrm{KE}=210.3+89 \log _{10} \mathrm{I}(3)$

Where, $\mathrm{KE}=$ Kinetic energy in metric ton.m/ha.cm

$\mathrm{I}=$ Rainfall intensity in $\mathrm{cm} / \mathrm{hr}$. 
Since daily rainfall data of recording type raingauge were available only for 3 years (2014 to 2016), we used these data to compute $\mathrm{KE}$ (Eq. 3) and these values of KE was used to compute corresponding $\mathrm{R}$ values (Eq. 2). In the earlier studies, relationship between monthly $\mathrm{R}$ and rainfall (P) was established through regression analysis (Erasmus et al., 1970). In the present study, using the computed values of $\mathrm{R}$ and rainfall, $\mathrm{P}$ of these 3 years a linear regression model (Coefficient of determination, $\mathrm{R}^{2}=0.87$ ) was developed and expressed as:

$R=-23.15+0.308 P(4)$

Using the above Eq. (4), we estimated the value of $\mathrm{R}$ of each strom event of rest of the years of study using the values of $\mathrm{P}$ of each storm event. Considering the local traditional cropping practice, $\mathrm{R}$ value for entire crop growing season (kharif + rabi + summer) was considered for calculation of soil loss. The values of soil erodibility factor $(\mathrm{K})$ and slope gradient factor (LS) were determined as the area weightage value of considering range of values of $\mathrm{K}$ and $\mathrm{LS}$ for different land masses respectively as given by Sahoo et al., (2013) for the Andaman and Nicobar group of islands. The area weighted values of $\mathrm{K}$ and LS were found to be 0.26 and 4.79 respectively. The value of crop management factor (C) of various crops and fallow land were taken from the published literature (Roose, 1976; Panigrahi, 2007) and are given in the Table 1. The value of supporting conservation practice factor $(\mathrm{P})$ was determined considering the crop wise conservation practice followed in the farmers' field of these islands (Table 2).

\section{Results and Discussion}

Major field crops grown in the district are vegetables, paddy, maize, ginger, sweet potato and turmeric. Vegetables and paddy are grown in an area of 1317.0 ha and 216.0 ha which accounts for $75 \%$ and $12 \%$ of the total cultivated area of 1747.8 ha respectively. Other crops cultivated in the area are maize (55.0 ha), ginger (51.5 ha), sweet potato (46.0 ha), tapioca (26.5 ha), turmeric (19.5 ha), green gram and black gram (13.7 ha). Among all the crops, paddy, maize, arhar, ginger, sweet potato, turmeric, tapioca and ground nut are grown in kharif season whereas, mustard, green gram, black gram and vegetables are grown in rabi season and only vegetables are grown in summer season.

Table.1 Values of crop management factor ' $C$ '

\begin{tabular}{|l|l|l|}
\hline Sl. No. & Crop & Value of ' $\mathbf{C}$ ' factor \\
\hline $\mathbf{1}$ & Rice & 0.28 \\
\hline $\mathbf{2}$ & Maize & 0.45 \\
\hline $\mathbf{3}$ & Green gram & 0.41 \\
\hline $\mathbf{4}$ & Black gram & 0.49 \\
\hline $\mathbf{5}$ & Arhar & 0.38 \\
\hline $\mathbf{6}$ & Ground nut & 0.36 \\
\hline $\mathbf{7}$ & Mustard & 0.30 \\
\hline $\mathbf{8}$ & Ginger & 0.30 \\
\hline $\mathbf{9}$ & Turmeric & 0.35 \\
\hline $\mathbf{1 0}$ & Sweet potato & 0.33 \\
\hline $\mathbf{1 1}$ & Tapioca & 0.50 \\
\hline $\mathbf{1 2}$ & Vegetable & 0.33 \\
\hline $\mathbf{1 3}$ & Fallow field & 1.00 \\
\hline
\end{tabular}


Table.2 Values of Conservation practice factor ' $\mathrm{P}$ '

\begin{tabular}{|l|l|l|}
\hline SI. No. & Conservation practice & P-factor values \\
\hline $\mathbf{1}$ & Contour bunding & 0.20 \\
\hline $\mathbf{2}$ & Field bunding & 0.30 \\
\hline $\mathbf{3}$ & Cultivated fallow & 1.00 \\
\hline
\end{tabular}

Source: Kurothe, 1991

Table.3 Month wise average rainfall and erosivity factor ' $R$ ' for the period 1978-2016

\begin{tabular}{|l|c|c|}
\hline Month & Rainfall $(\mathbf{m m})$ & R (metric ton.m/ha. hr) \\
\hline January & 44.67 & 3.33 \\
\hline February & 20.68 & 1.48 \\
\hline March & 46.61 & 7.99 \\
\hline April & 75.90 & 9.98 \\
\hline May & 436.51 & 111.30 \\
\hline June & 457.02 & 117.61 \\
\hline July & 457.14 & 117.90 \\
\hline August & 411.78 & 103.68 \\
\hline September & 505.89 & 132.67 \\
\hline October & 291.59 & 66.66 \\
\hline November & 226.97 & 47.21 \\
\hline December & 144.04 & 28.33 \\
\hline Total & $3,118.80$ & 748.14 \\
\hline
\end{tabular}

Table.4 Year wise rainfall and erosivity factor 'R' for the period 1978-2016

\begin{tabular}{|l|l|l|l|l|l|l|l|l|}
\hline Year & $\begin{array}{l}\text { Rainfall } \\
\text { (mm) }\end{array}$ & $\begin{array}{l}\mathbf{R} \text { (metric } \\
\text { ton.m/ } \\
\text { ha.hr) }\end{array}$ & Year & $\begin{array}{l}\text { Rainfall } \\
\text { (mm) }\end{array}$ & $\begin{array}{l}\text { R (metric } \\
\text { ton.m/ } \\
\text { ha.hr) }\end{array}$ & Year & $\begin{array}{l}\text { Rainfall } \\
\text { (mm) }\end{array}$ & $\begin{array}{l}\text { R (metric } \\
\text { ton.m/ } \\
\text { ha.hr) }\end{array}$ \\
\hline $\mathbf{1 9 7 8}$ & 2698.1 & 620.1 & 1991 & 3100.7 & 749.2 & 2004 & 2410.4 & 528.9 \\
\hline $\mathbf{1 9 7 9}$ & 1574.1 & 304.6 & 1992 & 2747.9 & 659.5 & 2005 & 3759.2 & 955.7 \\
\hline $\mathbf{1 9 8 0}$ & 3760.3 & 970.5 & 1993 & 2468.8 & 589.9 & 2006 & 3002.2 & 726.1 \\
\hline $\mathbf{1 9 8 1}$ & 3402.7 & 837.0 & 1994 & 3465.3 & 861.5 & 2007 & 2525.6 & 600.3 \\
\hline $\mathbf{1 9 8 2}$ & 2410.8 & 557.0 & 1995 & 3444.8 & 890.1 & 2008 & 4130.4 & 1047.2 \\
\hline $\mathbf{1 9 8 3}$ & 2903.0 & 706.3 & 1996 & 3356.4 & 800.6 & 2009 & 2551.4 & 572.8 \\
\hline $\mathbf{1 9 8 4}$ & 3498.9 & 796.3 & 1997 & 2701.5 & 643.7 & 2010 & 3110.2 & 747.3 \\
\hline $\mathbf{1 9 8 5}$ & 2690.5 & 640.9 & 1998 & 2756.8 & 672.1 & 2011 & 3827.6 & 909.1 \\
\hline $\mathbf{1 9 8 6}$ & 2024.3 & 450.7 & 1999 & 2966.4 & 661.2 & 2012 & 4006.9 & 992.6 \\
\hline $\mathbf{1 9 8 7}$ & 2657.6 & 628.0 & 2000 & 3158.2 & 705.2 & 2013 & 3406.6 & 846.8 \\
\hline $\mathbf{1 9 8 8}$ & 3285.5 & 801.4 & 2001 & 3127.2 & 723.3 & 2014 & 2915.9 & 716.4 \\
\hline $\mathbf{1 9 8 9}$ & 2613.3 & 608.0 & 2002 & 2512.3 & 565.5 & 2015 & 2808.4 & 631.1 \\
\hline $\mathbf{1 9 9 0}$ & 2681.0 & 615.3 & 2003 & 2428.1 & 536.1 & 2016 & 3541.4 & 872.4 \\
\hline
\end{tabular}


Fig.1 Rate of soil loss from mono crop lands

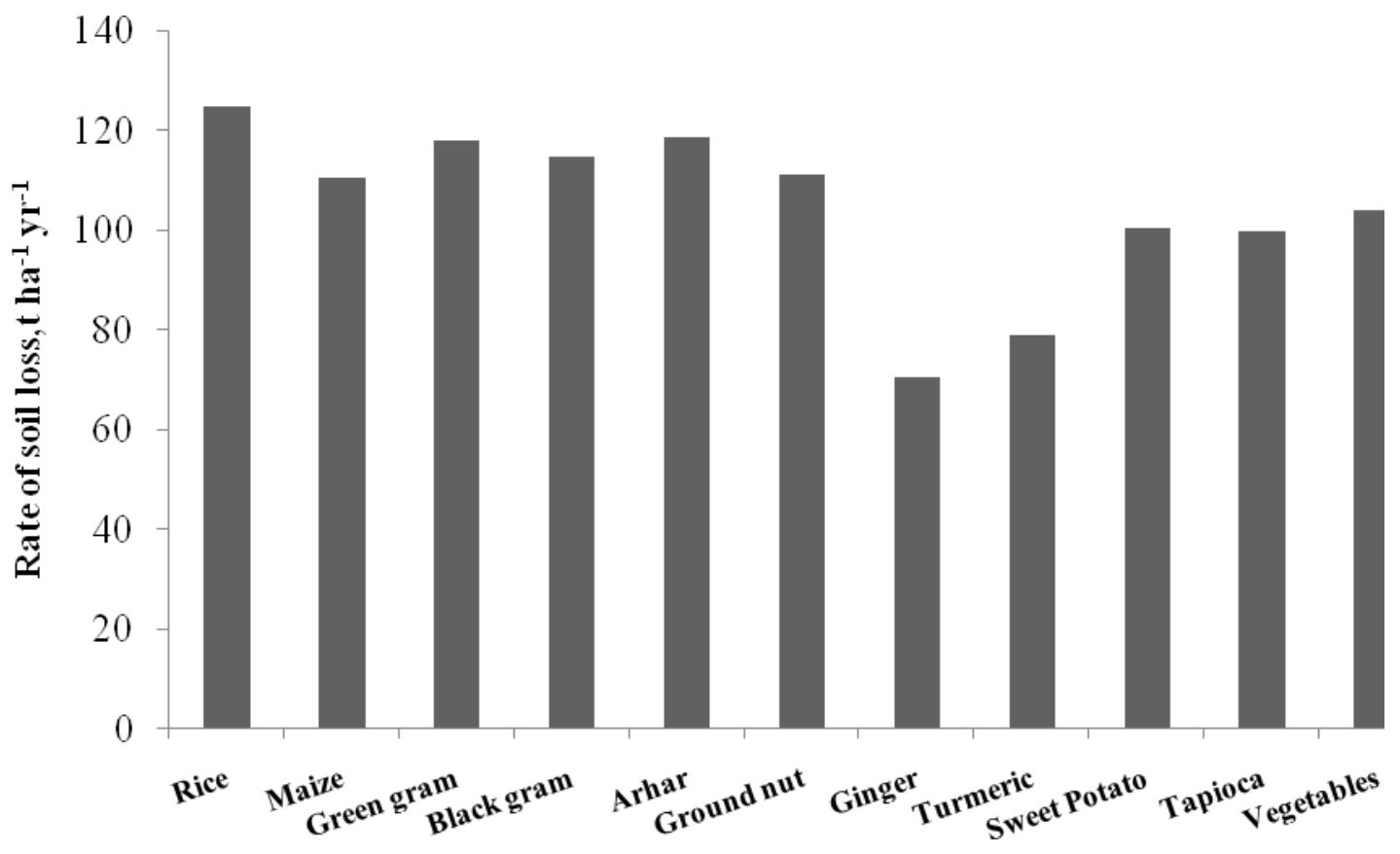

Fig.2 Rate of soil loss from double crop lands

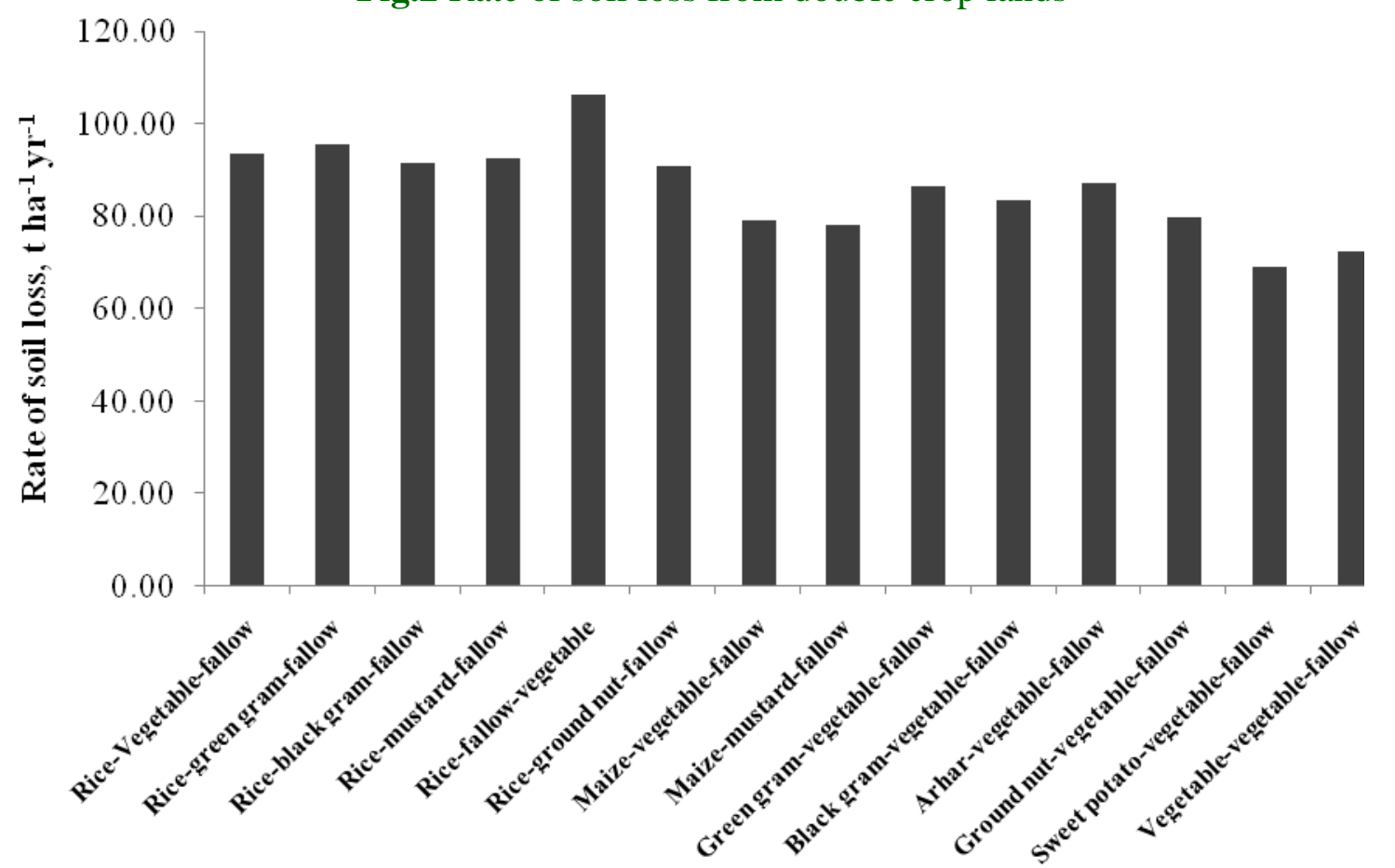

\section{Calculation of erosivity factor ' $R$ '}

The monthly values of $\mathrm{P}$ and $\mathrm{R}$ of all the years (1978-2016) were used to estimate the average values of $\mathrm{P}$ and $\mathrm{R}$ and are shown in
Table 3. The monthly values of $P$ and $R$ of each year were added to get the yearly values of $P$ and $R$. The values of so computed values of $\mathrm{P}$ and $\mathrm{R}$ of all the years are shown in Table 4. 
The values of erosivity factor varied from 1.48 metric ton.m/ha.hr (in February) to 132.67 metric ton.m/ha.hr (in September). This is due to the occurrence of more nos. of erosive storms in the month of September as compared to other months. The total annual $\mathrm{R}$-factor was found to be 748.14 metric ton.m/ha.hr with the highest and the lowest $\mathrm{R}$ values of 1047.2 metric ton.m/ha.hr and 304.6 metric ton.m/ha.hr in the year 2008 and 1979 respectively due to the rainfall variation (highest rainfall of $4130.4 \mathrm{~mm}$ in 2008 and the lowest rainfall of $1574.1 \mathrm{~mm}$ in 1979). Higher rainfall amount was observed during the months from May to October as compared to other months. The months from May to September showed R values of more than 100 metric ton.m/ha.hr (ranging from 103.68 to 132.67 metric ton.m/ha.hr) with an average of 116.6 metric ton.m/ha.hr per month.

Crop wise annual soil loss was also calculated. The annual soil loss of 184098.12 tons was recorded at the rate of $105.38 \mathrm{t} \mathrm{ha}^{-1}$ $\mathrm{yr}^{-1}$ from the agricultural fields of the South Andaman district. Among the mono crops, paddy contributes highest rate of soil loss $\left(124 \mathrm{t} \mathrm{ha}^{-1} \mathrm{yr}^{-1}\right)$ and ginger yields lowest rate of soil loss (70.6 t ha $\mathrm{yr}^{-1}$ ) (Fig. 1). Paddy crop contributed more soil loss due to longer fallow period and cultivation of crop on terraces. Waterlogging occurs rarely in these islands due to quick drainage of excess rainfall to the sea. Most of the cases standing crop during kharif suffers when there is a dry spell of more than a week. The areas with assured irrigation are double cropped and are very less in areal extent as cropping intensity of the district is 104.0\% (Nanda et al, 2018).

Among the double cropped lands (Fig. 2), the sequence of sweet potato-vegetable-fallow contributes lowest rate of soil loss $(68.76 \mathrm{tha}$ $\left.1 \mathrm{yr}^{-1}\right)$, where as the cropping sequence of rice-fallow-vegetable yield highest rate of soil loss $\left(106.25 \mathrm{t} \mathrm{ha}^{-1} \mathrm{yr}^{-1}\right)$. The average rate of soil loss from double cropped land was 86.02 $\mathrm{t} \mathrm{ha}^{-1} \mathrm{yr}^{-1}$. Since the average annual rate of soil loss in mono crop land was estimated as $105.38 \mathrm{t} \mathrm{ha}^{-1} \mathrm{yr}^{-1}$ and that of double cropped land was estimated as $86.02 \mathrm{t} \mathrm{ha}^{-1} \mathrm{yr}^{-1}$, it is assessed that there would be a reduction of $18.4 \%$ soil loss if the mono crop land is changed to double cropped land.

The rate of soil loss from the cropped land showed extremely severe soil erosion as it exceeds considerably the soil loss tolerance limit of $11.2 \mathrm{t} \mathrm{ha}^{-1} \mathrm{yr}^{-1}$ (Mannering, 1981). Soil loss tolerance is a limit which denotes the maximum level of soil erosion that will permit crop productivity to be sustained economically. Mannering, 1981 reported that the tolerance limits are ranging from 4.5 to $11.2 \mathrm{t} \mathrm{ha}^{-1} \mathrm{yr}^{-1}$ and soil loss in excess of $11.2 \mathrm{t}$ $\mathrm{ha}^{-1} \mathrm{yr}^{-1}$ affected the effectiveness of water conservation structures. At this stage, the gully formation starts which in turn obstructs the intercultural operation (Singh et al, 1981). It is a matter of serious concern that due to huge loss of surface soil on account of soil erosion, associated with macro, major and micronutrients are also lost recurrently each year leading to nutrient depletion and poor soil fertility. Therefore, good conservation planning in the union territory of Andamans is of utmost importance towards optimizing agricultural production.

\section{References}

Ahmad, I and Verma, M. K. 2013. Application of USLE Model \& GIS in Estimation of Soi Erosion for Tandula Reservoir. International Journal of Emerging Technology and Advanced Engineering, 3(4): 570-576.

Bhattacharyya, R., Ghosh, B. N., Mishra, P. K., Mandal, B., Rao, C. S., Sarkar, D., Das, K., Anil, K. S., Lalitha, M., Hati, K., M. and Franzluebbers, A. J. 2015. Soil degradation in India: Challenges 
and Potential Solutions. Sustainability, 7: 3528-3570.

Brandon, C., Hommann, K. and Kishore, N. M. 1995. The cost of inaction: Valuing the economy wide cost of environmental degradation in India. In Proceedings of the UNU Conference on the sustainable future of the global system, Tokyo, 16-18 Oct, 1995.

District Statistical Hand Book. 2011. Directorate of Economics and Statistics, Andaman and Nicobar Administration, Port Blair, 64p

Erasmus, I. E., Lal, M., Raghunath, B. and Mathur, P. S. 1970. Evaluation of erosion potential for daily rainfall data. Indian Forester, 96 (II), 817-825

http://agri.and.nic.in/soilconservation.html. Soil Conservation in Andaman and Nicobar Islands.

ICAR-CIARI, 2017. Annual Report 2016-17. ICAR-Central Island Agricultural Research Institute, Post Box No. 181, Port Blair, Andaman and Nicobar Group of Islands, India. 265p

ICAR-KVK, 2018. Annual Report 2017-18. ICAR-Krishi Vigyan Kendra, Port Blair, Andaman and Nicobar Group of Islands, India. 118p

Kurothe, R. S. 1991. Soil erosion map of Gujarat. Indian Journal of Soil Conservation, 25(1):9-13

Mannering, J. V. 1981. The use of soil tolerances as strategy for soil conservation. Soil Conservation problem and prospect. R. P. C. Morgan Jhon willey \& Sons, Chichester England, pp. 337-349.

Naik, B. S., Paul, J. C., Panigrahi, B. and Sahoo, B. C. 2015. Soil erosion assessment from farming lands of Koraput district in Eastern Ghat region of Odisha. Indian Journal of Soil Conservation, 43 (1): 33-37.

Naik, B. S., Paul, J. C., Panigrahi, B. and Sahoo, B. C. 2014. Soil loss from agricultural lands in eastern ghat of Odisha - A case study of Koraput district. Journal of Soil and Water Conservation, 13 (4): 324-329.

Nanda, B. K., Sahoo, N. and Panigrahi, B. 2018. Agroclimatic conditions, cropping pattern and its profitability in South Andaman district of Bay Islands. Journal of Krishi Vigyan, 7(1): 4-9.

Narain, P., Singh, R. K., Sindhwal, N. S. and Joshi, P. 1998. Agroforestry for soil and water conservation in the Western Himalaya valley region of India: Runoff, soil and nutrient losses. Agroforestry Systems, 39: 175-189.

Oldeman, L. R. and Van Lynden, G. W. J. 1997. The Assessment of the Status of Human- Induced Soil Degradation in South and Southeast Asia. International Soil Reference and Information Centre Wageningen, February 1997. http://www.isric.

org/ISRIC/webdocs/docs/assodendrepor t.pdf.

Pandey, C. B., Rai, R. B., Singh, L. and Singh, A. K. 2007. Homegardens of Andaman and Nicobar, India. Agricultural Systems, 92:1-22.

Pandey, C. B. and Singh, L. 2009. Soil fertility under homegarden trees and native moist evergreen forest in South Andaman, India. Journal of Sustainable Agriculture, 33(30): 303-318.

Panigrahi, D. 2007. Water and land use optimization in hill plateaus of Orissa. Unpublished Ph. D. Thesis, Utkal University, Bhubaneswar.

Panigrahi, D., Acharya, M. and Senapati, P. C. 2009. Estimation of Soil Loss from Croplands of Kandhamal Plateau in Orissa. Indian Journal of Dryland Agriculture Research \& Development, 24(1): 52-56.

Pimentel, D., Harvey, C., Resosudarmo, K., Sinclair, K., Kurz, D., McNair, M., Crist, S., Shpritz, L., Fitton, L., 
Saffouri, R. and Blair, R. 1995. Environmental and Economic Costs of Soil Erosion and Conservation Benefits. Science, 267:1117-1123.

Raghunath, B. and Erasmus, I. E. 1971. A method for estimating erosion potential from daily rainfall data. Indian Forester. 97(3): 121-125.

Roose, E. J. 1976. Use of the universal soil loss equation to predict erosion in West Africa. In: Soil Erosion: Prediction and Control, Soil Conservation Society of America, Ankeny, Iowa, 60-74.

Sahoo, A. K., Das, K., Das, A. L., Obi Reddy, G. P., Singh, S. K., Sarkar, D. and Mishra, P. K. 2013. Soil Erosion of Andaman \& Nicobar Islands. NBSS Publ. No. 165, NBSS\&LUP (ICAR), Nagpur, 30p

Singh, G., Ram Babu and Chandra, S. 1981. Soil loss prediction research in India. Bull. No. T-12/D-9, CSWCRTI, Dehradun.
Suresh, R., Das, G. and Singh, J. K. 2002. Estimation of soil loss generating potential of various land use activities in Naurar watershed of Ramganga catchment, UP (India). Journal of Indian Water Resource Society, 22(3):107-116.

Velmurugan, A., Swarnam, T. P., Kumar, P. and Ravishankar, N. 2008. Soil erosion assessment using revised Morgan, Morgan Finney model for prioritization of Dhanikhari watershed in South Andaman. Indian Journal of Soil Conservation, 36(3):173-179.

Wischmeir, W. H. 1959. A rainfall erosion index for Universal Soil Loss Equation. Soil Science Society of America Proceedings. 23: May-June. 246-249.

Wischmeier, W. H. and Smith, D. D. 1978. Predicting rainfall-erosion losses: a guide to conservation planning. In: U.S. Dept. of Agriculture, Agriculture Handbook book \# 537.

\section{How to cite this article:}

Nanda, B.K., N. Sahoo and Panigrahi, B. 2019. Assessment of Soil Loss from Agricultural Lands of South Andaman District in Tropical Islands. Int.J.Curr.Microbiol.App.Sci. 8(03): 2190-2198. doi: https://doi.org/10.20546/ijcmas.2019.803.262 